\title{
Arsenate (As) uptake by and distribution in two cultivars of winter wheat (Triticum aestivum L.)
}

\author{
Chun-Nu Geng a,b, Yong-Guan Zhu ${ }^{\text {a,* }}$, Yi-Ping Tong ${ }^{\text {a }}$, \\ Sally E. Smith ${ }^{\mathrm{c}}$, F.A. Smith ${ }^{\mathrm{c}}$ \\ a Research Center for Eco-Environmental Sciences, Chinese Academy of Sciences, Beijing 100085, China \\ b Shanghai Academy of Environmental Sciences, 508 Qingzhou Road, Shanghai, China \\ ${ }^{\mathrm{c}}$ School of Earth and Environmental Sciences, The University of Adelaide, Adelaide SA5005, Australia
}

Received 7 September 2004; received in revised form 13 May 2005; accepted 28 May 2005

Available online 2 August 2005

\begin{abstract}
Two cultivars of winter wheat (Triticum aestivum L.) (Jing 411 and Lovrin 10) were used to investigate arsenate (As) uptake and distribution in plants grown in hydroponic culture and in the soil. Results showed that without As addition, Lovrin 10 had higher biomass than Jing 411 in the soil pot experiment; in the hydroponic experiment Lovrin 10 had similar root biomass to and lower shoot biomass than Jing 411. Increasing P supply from 32 to $161 \mu \mathrm{M}$ resulted in lower tissue As concentrations, and increasing As supply from 0 to $2000 \mu \mathrm{M}$ resulted in lower tissue P concentrations. Increasing $\mathrm{P}$ supply tended to increase shoot-to-root ratios of As concentrations, and increasing As supply tended to decrease shoot-to-root ratios of As concentrations. Both cultivars invested more in root production under $\mathrm{P}$ deficient conditions than under P sufficient conditions. Lovrin 10 invested more biomass production to roots than Jing 411, which might be partly responsible for higher shoot $\mathrm{P}$ and As concentrations and higher shoot-to-root ratios of As concentrations. Moreover, Lovrin 10 allocated less As to roots than Jing 411 and the difference disappeared with decreasing P supply. (c) 2005 Elsevier Ltd. All rights reserved.
\end{abstract}

Keywords: Triticum aestivum; Arsenic (As); P efficiency; As uptake; As distribution

\section{Introduction}

Arsenic (As) may play an essential role in animal nutrition (Uthus, 1992, 1994), possibly in methionine metabolism, but it is generally considered as an element highly toxic to plants and animals (National Research Council, 1977). Indeed, arsenic toxicity in humans has recently received increasing attention due to large scale

\footnotetext{
* Corresponding author. Tel.: +86 106293 6940; fax: +86 10 62923563.

E-mail address: ygzhu@mail.rcees.ac.cn (Y.-G. Zhu).
}

As contamination in regions such as Bangladesh (Dhar et al., 1997) and northwest China (L.F. Wang et al., 2002). Arsenic can be derived from both geogenic (Juhasz et al., 2003) and anthropogenic sources, such as mining and agricultural activities (Xie et al., 1997; Wang et al., 1999). As a result of this environmental contamination, tens of millions of people are exposed to elevated levels of As in drinking water and diets. It is reported that in the vicinity of an As mine in Hunan, China, as high as $35 \%$ of the local population had severe arsenism, and that the percentage increased with age (Wang et al., 1999). Epidemiological studies further demonstrated that there was a significant correlation between As concentrations 
in human hairs and those in local rice (Oryza sativa L.), wheat (Triticum aestivum L.) and soils (Lin et al., 2001). It is generally accepted that soil-plant transfer of As is one of the principal pathways for human exposure to As.

Inorganic arsenic (arsenate and arsenite) is highly toxic to plants because it uncouples phosphorylation and inhibits phosphate uptake. At higher concentrations, arsenic interferes with plant metabolic processes and can inhibit growth, and under severe conditions may lead to plant death. For example, biomass production and yields of a variety of crops were reduced significantly at elevated As concentrations (Carbonell-Barrachina et al., 1997). The concentration of $50 \mathrm{mg}$ As $\mathrm{kg}^{-1}$ in soil significantly decreased the yields of barley (Hordeum vulgare L.) and ryegrass (Lolium perenne L.) (Jiang and Singh, 1994). Arsenate, the dominant form of As in aerated conditions, is taken up by plants via the phosphate $(\mathrm{Pi})$ transport systems because of the chemical similarity between arsenate and Pi (Dixon, 1997). It has been demonstrated that arsenate inhibits Pi uptake by yeast (Rothstein and Donovan, 1963), phytoplankton (Blum, 1966), Arabidopsis thaliana (Clark et al., 2003) and the As hyperaccumulator, Chinese brake fern Pteris vittata (J.R. Wang et al., 2002). Similarly, Pi suppresses arsenate uptake by phytoplankton (Planas and Healey, 1978), rice (Abedin et al., 2002), Lupinus albus (Esteban et al., 2003), the As tolerant plants Holcus lanatus and Cytisus striatus (Meharg and Macnair, 1992; Bleeker et al., 2003), and P. vittata (J.R. Wang et al., 2002; Tu and Ma, 2003).

Under field conditions, the wheat cultivar Lovrin 10 has been identified as more efficient than cultivar Jing 411 in P uptake and utilization (Davies et al., 2002). In wheat, several $\mathrm{Pi}$ transporters have been identified and the expression pattern of phosphate transporters differs between these two cultivars (Davies et al., 2002). Since arsenate was taken up by phosphate transporters, these two cultivars may also show different patterns of As uptake and translocation. Thus the objectives of this study were to investigate the difference in As uptake and translocation between cultivars Jing 411 and Lovrin 10, grown in solution and soil.

\section{Materials and methods}

\subsection{Plant culture in hydroponics}

Seeds of two winter wheat cultivars Jing 411 and Lovrin 10 were sterilized in $10 \% \mathrm{H}_{2} \mathrm{O}_{2}(\mathrm{w} / \mathrm{w})$ for $10 \mathrm{~min}$ followed by thorough washing in de-ionized water, and then germinated on moist filter paper for 2 days. Germinated seeds were transferred to moist perlite and cultivated for 10 days. The seedlings were then removed from the perlite and were washed carefully under tap water to remove any adhering particles. Seedlings were then transferred to PVC pots containing $500 \mathrm{ml}$ modified Hoagland's solution containing (in $\mathrm{mM}$ ): $\mathrm{KNO}_{3}, 2.0$; $\mathrm{Ca}\left(\mathrm{NO}_{3}\right)_{2}, 2.0 ; \mathrm{MgSO}_{4}, 0.7$; and (in $\mu \mathrm{M}$ ), FeEDTA, 50; $\mathrm{ZnSO}_{4}, 0.5 ; \mathrm{CuSO}_{4}, 0.5 ; \mathrm{MnSO}_{4}, 2.5 ; \mathrm{H}_{3} \mathrm{BO}_{3}, 5$; $\mathrm{Na}_{2} \mathrm{MoO}_{4}, 0.25 ; \mathrm{CoSO}_{4}, 0.09 ; \mathrm{NaCl}, 50$. The solution was supplemented with two P concentrations (32 or 161 $\mu \mathrm{M})$ as $\mathrm{KH}_{2} \mathrm{PO}_{4}$. Ten days later the solutions were amended with three As concentrations $(0,3.3$ and 6.7 $\mu \mathrm{M})$ as $\mathrm{Na}_{3} \mathrm{AsO}_{4} \cdot 12 \mathrm{H}_{2} \mathrm{O}$ and the corresponding $\mathrm{P}$ concentrations for another 13 days. Altogether there were six treatments of $\mathrm{P}$ and As levels with four replicates for each treatment. The seedlings were grown in a growth chamber with $14 / 10 \mathrm{~h}$ light/dark cycles, temperature was kept at $28^{\circ} \mathrm{C}$ during the day and $20^{\circ} \mathrm{C}$ during the night. Light intensity was around $280 \mu \mathrm{mol} \mathrm{m} \mathrm{m}^{-2} \mathrm{~s}^{-1}$. The nutrient solution was rene-wed twice a week and aerated continuously. Pots were randomly arranged every day during the growth period.

\subsection{Plant culture in the soil pot experiment}

A low P soil was taken from the Luancheng Experimental Station, Chinese Academy of Sciences $\left(37^{\circ} 50^{\prime} \mathrm{N}\right.$, $\left.114^{\circ} 40^{\prime} \mathrm{E}\right)$. Soil chemical properties were measured using methods recommended by the Chinese Society of Soil Science ( $\mathrm{Lu}, 1999)$. The selected chemical properties of the soil are as follows: $\mathrm{pH} 7.74$, OM $1.75 \%$, Olsen-P $4.55 \mathrm{mg} \mathrm{kg}^{-1}$, and total As $10.1 \mathrm{mg} \mathrm{kg}^{-1}$. Uniform fertilizers were amended as follows: $14.3 \mathrm{mM} \mathrm{N}$ as $\mathrm{NH}_{4} \mathrm{NO}_{3}$, $1 \mathrm{mM} \mathrm{P}$ as $\mathrm{KH}_{2} \mathrm{PO}_{4}$ and $3.8 \mathrm{mM} \mathrm{K}$ as $\mathrm{K}_{2} \mathrm{SO}_{4}$. Three As concentrations $\left(0,667\right.$ and $2000 \mu \mathrm{M}$ as $\mathrm{Na}_{3} \mathrm{AsO}_{4} \cdot 12$ $\mathrm{H}_{2} \mathrm{O}$ ) were also added into the soil. Seven days later, the soil was packed into plastic pots, each pot contained $500 \mathrm{~g}$ soil. Seeds of Jing 411 and Lovrin 10 were sterilized and germinated as in hydroponics and germinated seeds were transferred to plastic pots. Ten days later the seedlings were thinned to two per pot. Each treatment had four replicates. The seedlings were grown in the greenhouse for 70 days with a $12 / 12 \mathrm{~h} \mathrm{light/dark}$ cycle and a light intensity of about $280 \mu \mathrm{mol} \mathrm{m}{ }^{-2} \mathrm{~s}^{-1}$. The pots were re-randomized daily during the growth period. Soil moisture content was regularly adjusted to $30 \%$ by weight with de-ionized water.

\subsection{Plant analysis}

At harvest, plants were divided into roots and shoots. Plant materials were then oven dried at $70^{\circ} \mathrm{C}$ for $48 \mathrm{~h}$ and the dry weights of shoots and roots were recorded. Dried shoots and roots were finely ground in a stainless steel miller. The powdered dry materials were digested in $5 \mathrm{ml}$ of high-purity concentrated nitric acid, first at $80^{\circ} \mathrm{C}$ for $2 \mathrm{~h}$ and then $120^{\circ} \mathrm{C}$ for $20 \mathrm{~h}$. The As and $\mathrm{P}$ concentrations of the solution were determined by ICP-OES (inductively coupled plasma optical emission spectrometer, Optima 2000 DV, Perkin-Elmer, USA). The As 
concentrations in shoots were generally lower than those in roots, and were determined by an AF-610A atomic fluorescence spectrometry (Beijing Ruili Analytical Instrument Co., Beijing, China). Standard material (tea leaves, obtained from China Standard Material Center) was used to ensure the accuracy of digestion and analysis. No As was detected in wheat with no As addition.

\subsection{Data analysis}

$\mathrm{P}$ and As distribution between roots and shoots were calculated as the percentages of $\mathrm{P}$ or As uptake to roots with respect to total $\mathrm{P}$ or As uptake (root + shoot), respectively.

All data were subjected to analysis of variance (ANOVA) performed on the Windows-based Genstat package (sixth ed., NAG Ltd., England).

\section{Results}

\subsection{Plant growth response}

In the hydroponic experiment, arsenic supply slightly reduced both root and shoot biomass (Table $1, P=0.012$ and 0.008 , respectively). For both cultivars $\mathrm{P}$ supply slightly reduced root dry weights, but markedly increased shoot dry weights $(P=0.007$ and $P<0.001$, respectively). Increasing external $P$ concentrations resulted in a reduction in the percentages of biomass allocated to roots $(P<0.001)$. At the same $\mathrm{P}$ and As supply, Jing 411 had higher shoot biomass, but lower percentages of biomass allocated to roots than Lovrin $10(P<0.001)$.

In the soil pot experiment, without As addition, Lovrin 10 had higher root and shoot biomass than Jing 411 (Table 2, $P<0.001$ ). At As addition of $667 \mu \mathrm{M}$, Lovrin 10 had lower shoot biomass than Jing 411. Lovrin 10 always invested more in root biomass than Jing 411 irrespective of As addition.

\subsection{As concentrations in roots and shoots}

In the hydroponic experiment, As supply markedly increased root and shoot As concentrations, but P supply markedly decreased As concentrations in roots and shoots (Fig. 1, $P<0.001$ ). At the same $\mathrm{P}$ and As supply, the two cultivars had similar root As concentrations, but Lovrin 10 higher shoot As concentrations than Jing 411 $(P<0.001)$.

Table 1

Root and shoot biomass and the percentages of biomass allocated to roots in two wheat cultivars (Jing 411 and Lovrin 10) pretreated with 32 and $161 \mu \mathrm{M}$ P for $10 \mathrm{~d}$ and then exposed to three As concentrations $(0,3.3,6.7 \mu \mathrm{M})$ and the corresponding P concentrations (32 and $161 \mu \mathrm{M}$ ) for another $13 \mathrm{~d}$ in hydroponics (mean $\pm \mathrm{SE}, n=4$ )

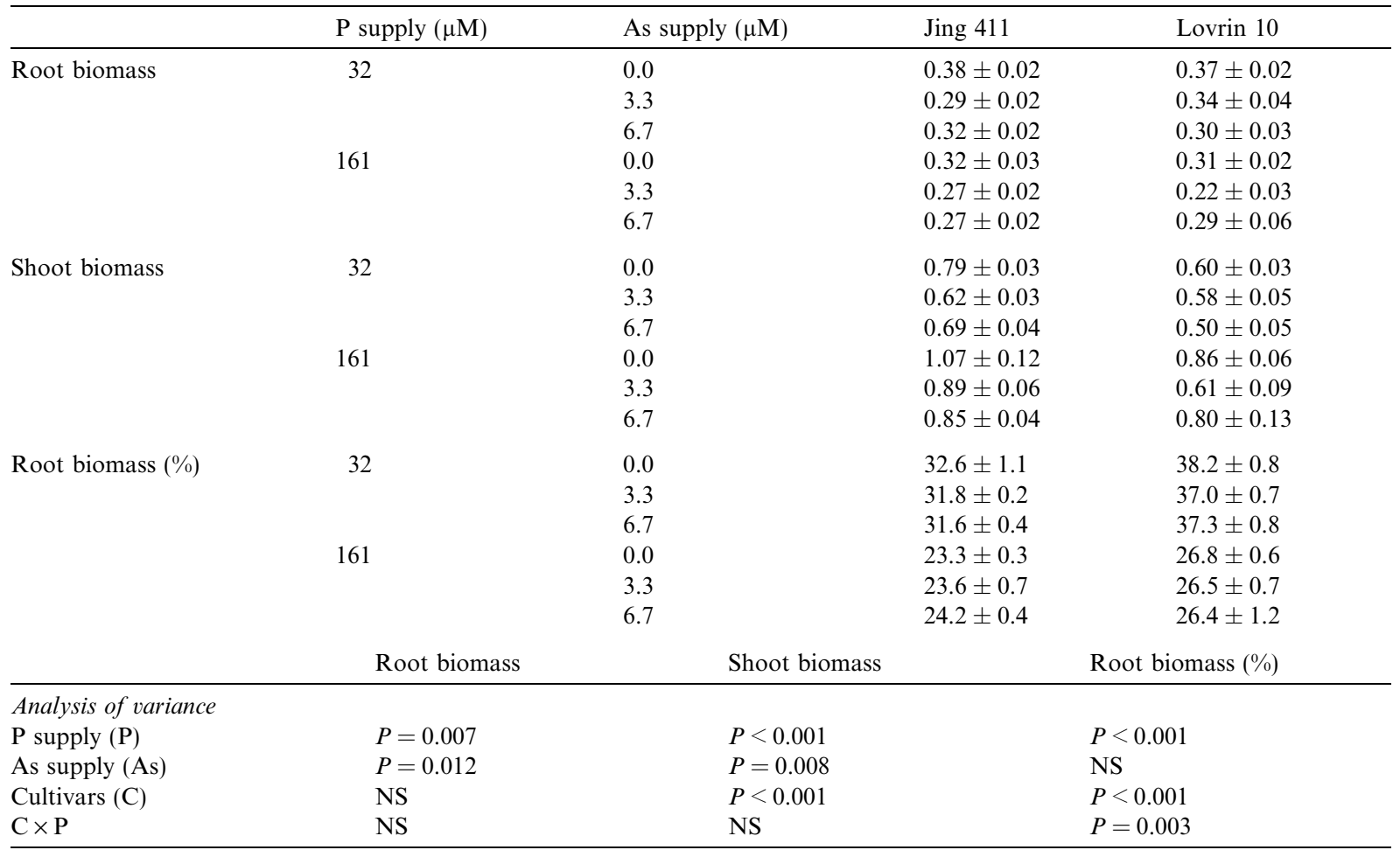

NS indicates not significant, $P>0.05$. 
Table 2

Root and shoot biomass and the percentages of biomass allocated to roots in two wheat cultivars (Jing 411 and Lovrin 10) exposed to three As concentrations $(0,667$ and $2000 \mu \mathrm{M})$ and $1 \mathrm{mM} P$ in the soil for $70 \mathrm{~d}$

\begin{tabular}{llll}
\hline & As supply $(\mu \mathrm{M})$ & Jing 411 & Lovrin 10 \\
\hline Root biomass & 0 & $0.99 \pm 0.08$ & $1.50 \pm 0.03$ \\
& 667 & $0.44 \pm 0.01$ & $0.44 \pm 0.02$ \\
& 2000 & $0.05 \pm 0.01$ & $0.07 \pm 0.01$ \\
Shoot biomass & 0 & $2.92 \pm 0.29$ & $3.85 \pm 0.19$ \\
& 667 & $1.35 \pm 0.08$ & $0.76 \pm 0.04$ \\
& 2000 & $0.15 \pm 0.01$ & $0.16 \pm 0.01$ \\
Root biomass \% & 0 & $25.4 \pm 0.8$ & $28.2 \pm 1.4$ \\
& 667 & $24.5 \pm 1.6$ & $36.9 \pm 0.9$ \\
& 2000 & $24.7 \pm 0.7$ & $29.5 \pm 2.1$ \\
& Root & Shoot & Root \\
\hline Analysis of variance & biomass & & biomass $\%$ \\
As supply (As) & $P<0.001$ & $P<0.001$ & $P=0.017$ \\
Cultivars (C) & $P<0.001$ & NS & $P<0.001$ \\
As $\times$ C & $P<0.001$ & $P<0.001$ & $P=0.005$ \\
\hline NS indicass & & &
\end{tabular}

NS indicates not significant, $P>0.05$.

$\mathrm{P}$ addition tended to increase and $\mathrm{As}$ addition tended to decrease shoot-to-root ratios of As concentrations (Table $3, P<0.001$ ). At the same $\mathrm{P}$ and As supply, Lovrin 10 had higher shoot-to-root ratios of As concentrations than Jing $411(P<0.001)$.

In the soil pot experiment, at the As addition of $2000 \mu \mathrm{M}$, Lovrin 10 had higher tissue As concentrations than Jing 411. At As addition of $667 \mu \mathrm{M}$, Lovrin 10 had lower shoot As concentrations than and similar root As concentrations to Jing 411 (Fig. 2, $P<0.001$ ).

\subsection{P concentrations in roots and shoots}

$P$ concentrations in roots were not shown due to their similar pattern to shoot $\mathrm{P}$ concentrations. In hydroponics, increasing external $P$ concentrations significantly enhanced $\mathrm{P}$ concentrations in roots and shoots irrespective of cultivars and external As concentration (Fig. 3(a), $P<0.001)$. Arsenic addition had little effect on $\operatorname{root} \mathrm{P}$ concentrations, but slightly increased shoot $\mathrm{P}$ concentrations $(P<0.001)$. At the same $\mathrm{P}$ and As supply, Lovrin 10 had higher shoot $\mathrm{P}$ concentrations than Jing 411 $(P<0.001)$, but there was no difference in root $\mathrm{P}$ concentrations between the two cultivars.

In the soil pot experiment, arsenic addition to the soil resulted in lower tissue $\mathrm{P}$ concentrations (Fig. 3(b), $P<0.001)$. With no As addition, Lovrin 10 had lower tissue $\mathrm{P}$ concentrations, and with As addition the difference in shoot $\mathrm{P}$ concentrations between the cultivars tended to disappear.
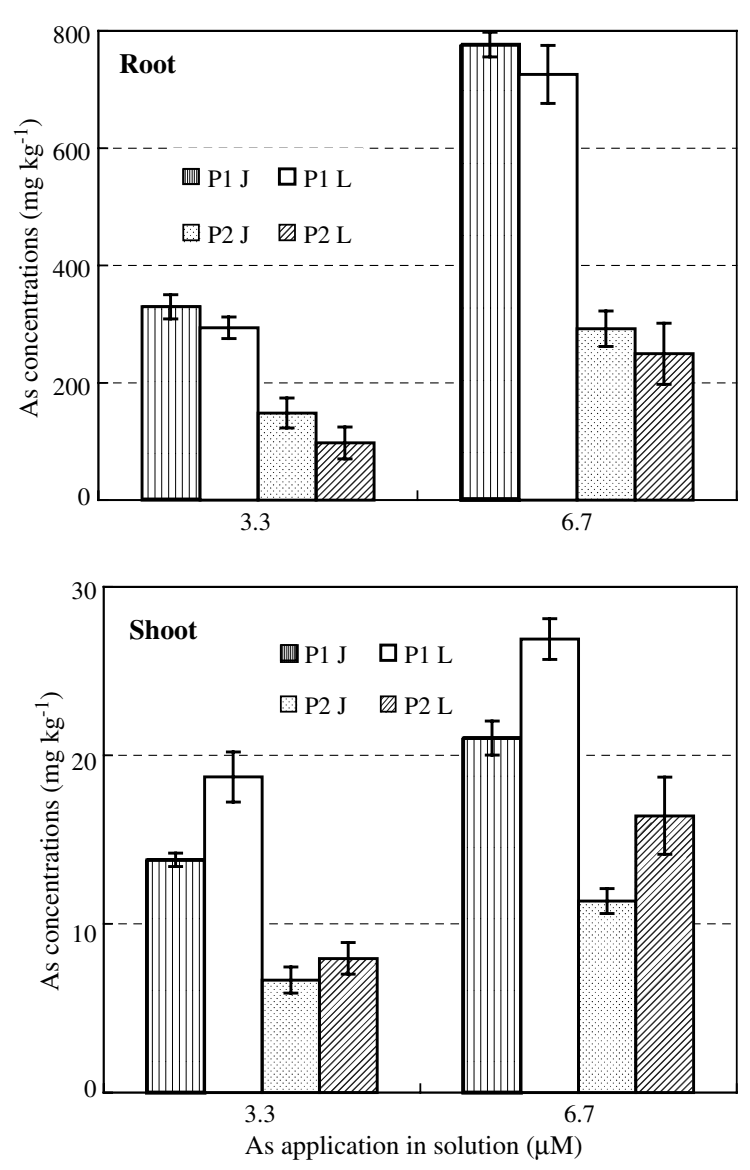

Fig. 1. Root and shoot As concentrations in two wheat cultivars (Jing 411 and Lovrin 10) pretreated with 32 and $161 \mu \mathrm{M}$ P for $10 \mathrm{~d}$ and then exposed to two As concentrations (3.3 and $6.7 \mu \mathrm{M}$ ) and the corresponding $\mathrm{P}$ concentrations (32 and $161 \mu \mathrm{M}$ ) for another $13 \mathrm{~d}$ in hydroponics. P1 and P2 refer to 32 and $161 \mu \mathrm{M}$ P supply, respectively. $\mathrm{J}$ and $\mathrm{L}$ refer to two wheat cultivars Jing 411 and Lovrin 10, respectively. Error bars represent standard errors of means from four replicates.

\subsection{As and P distribution between roots and shoots}

In the hydroponic experiment, for both cultivars, $\mathrm{P}$ supply resulted in significantly lower $\mathrm{P}$ and As allocation to roots (Fig. $4, P<0.001$ ). At $32 \mu \mathrm{M} \mathrm{P}$, there was little difference in As allocation to roots between the two cultivars at both As concentrations. However, at $161 \mu \mathrm{M} \mathrm{P}$, Lovrin 10 had lower As allocation to roots than Jing 411 at both As concentrations $(P<0.001)$.

\section{Discussion}

Since plant uptake of arsenate is mainly via phosphate (Pi) transporters (e.g. Clark et al., 2003), it has been well documented that Pi can effectively reduce plant uptake of 
Table 3

Shoot-to-root ratios of As concentrations in two wheat cultivars (Jing 411 and Lovrin 10) pretreated with 32 and $161 \mu \mathrm{M} P$ for $10 \mathrm{~d}$ and then exposed to three As concentrations $(0,3.3,6.7 \mu \mathrm{M})$ and the corresponding $P$ concentrations (32 and $161 \mu \mathrm{M})$ for another $13 \mathrm{~d}$ in hydroponics $\left(\times 10^{-3}\right.$, mean $\pm \mathrm{SE}$, $n=4)$

\begin{tabular}{llll}
\hline P supply $(\mu \mathrm{M})$ & As supply $(\mu \mathrm{M})$ & Jing 411 & Lovrin 10 \\
\hline 32 & 3.3 & $43 \pm 7$ & $64 \pm 4$ \\
& 6.7 & $27 \pm 4$ & $37 \pm 4$ \\
161 & 3.3 & $46 \pm 5$ & $92 \pm 28$ \\
& 6.7 & $40 \pm 5$ & $68 \pm 11$ \\
\hline
\end{tabular}

Analysis of variance

$\mathrm{P}$ supply (P)

As supply (As)

$<0.001$

Cultivars (C)

$<0.001$

$\mathrm{P} \times$ As

$<0.001$

$\mathrm{P} \times \mathrm{C}$

$<0.001$

As $\times$ C

$<0.001$

$<0.001$

$\mathrm{P} \times \mathrm{As} \times \mathrm{C}$

$<0.001$

arsenate, and arsenate can also inhibit plant uptake of $\mathrm{Pi}$ (Abedin et al., 2002; Esteban et al., 2003). Under hydroponic conditions, our results confirmed that increasing $\mathrm{Pi}$ concentrations in the external solution significantly hindered arsenate uptake by winter wheat (Fig. 1). Although $\mathrm{P}$ inhibited both root and shoot As concentrations, the reduction in roots seemed greater than that in shoots (Fig. 1), Moreover, although both root and shoot As concentrations increased with As additions, root As concentrations increased more rapidly than shoot As (Fig. 1). These data suggested that roots were more sensitive to $\mathrm{P}$ and As supply than shoots. J.R. Wang et al. (2002) also found that the inhibitory effect of P on As was more apparent in roots than in shoots.

However, increasing arsenate concentration in the growth solution did not affect $\mathrm{P}$ concentrations in plant roots, and marginally increased shoot $\mathrm{P}$ concentrations (albeit statistically significant). In the soil experiment, the addition of arsenate caused substantial reduction in $\mathrm{P}$ concentrations in both roots and shoots, this could be due to the much higher dose of arsenate freshly spiked into the soil used in the this experiment (Fig. 3).

High efficiency of $\mathrm{P}$ uptake by plants growing in soil can mainly be ascribed to (1) the mobilization of sparingly soluble $\mathrm{P}$ in the rhizosphere; (2) root architecture and the density of Pi transporters on root cell membranes; (3) symbiotic association with mycorrhizal (especially arbuscular mycorrhizal) fungi (Föhse and Jungk, 1983; Bates and Lynch, 1996; Neumann et al., 2000; Zhu and Smith, 2001). However, in solution culture high $\mathrm{P}$ uptake efficiency can only depend on root architecture and the density of Pi transporters. Under field conditions, Lovrin 10 has been identified as more efficient than Jing 411 in $\mathrm{P}$ uptake and utilization (Davies et al., 2002). In the present hydroponic study, irrespec-
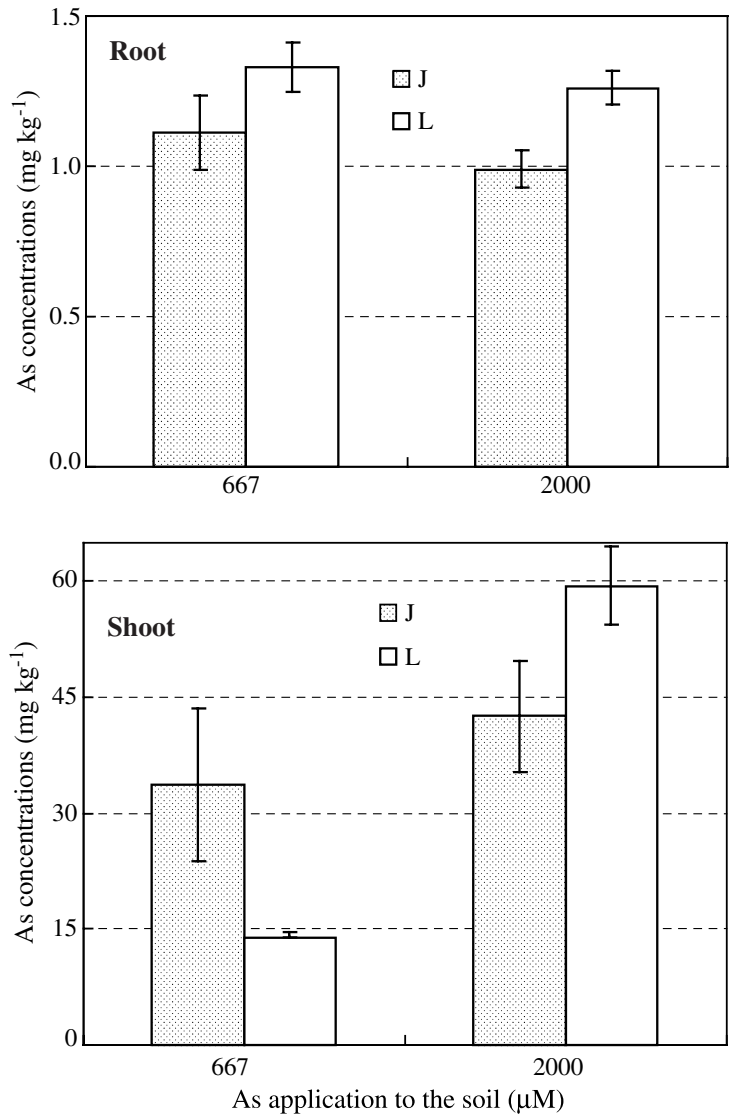

Fig. 2. Root and shoot As concentrations in two wheat cultivars (Jing 411 and Lovrin 10) exposed to two As concentrations $(667$ and $2000 \mu \mathrm{M})$ and $1 \mathrm{mM} \mathrm{P}$ in the soil for $70 \mathrm{~d}$. J and L refer to two wheat cultivars Jing 411 and Lovrin 10, respectively. Error bars represent standard errors of means from four replicates.

tive of external As concentrations, there were no significant differences in root biomass between the two cultivars (Fig. 1), but both cultivars allocated relatively more biomass and more absorbed $\mathrm{P}$ into roots (higher root/shoot ratios) under low $\mathrm{P}$ conditions $(32 \mu \mathrm{M})$ than under higher $\mathrm{P}$ conditions $(161 \mu \mathrm{M}$; Table 1$)$, which is a standard plant response to $\mathrm{P}$ deficiency (Chapin and Bieleshi, 1982). Lovrin 10 always had relatively more biomass allocated to roots than Jing 411, which is in agreement with the findings by Zou et al. (2002). In the present study, under hydroponic conditions, higher biomass allocation to roots by Lovrin 10 may contribute to relatively higher $\mathrm{P}$ concentrations in shoots. This biomass allocation pattern may also contribute to the higher As concentrations in shoots of Lovrin. However, under the conditions of soil pot experiment, higher biomass allocation to roots did not result in higher shoot $\mathrm{P}$ concentrations. In fact with no As addition, tissue P concentrations in Lovrin 10 was lower than those in Jing 

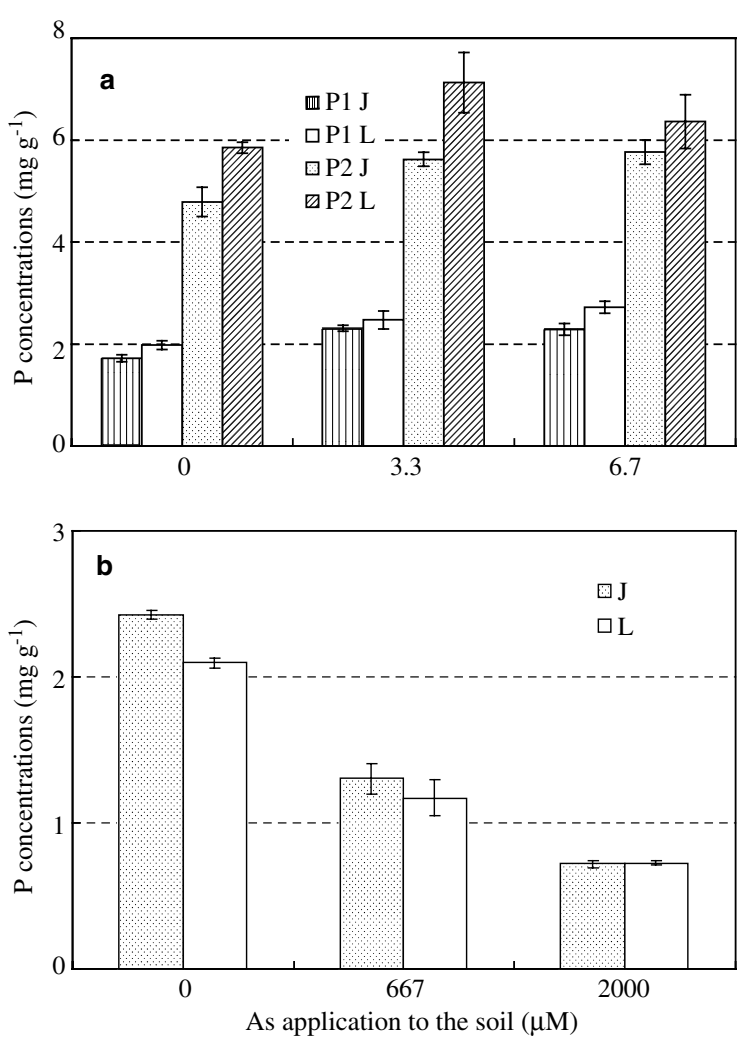

Fig. 3. Shoot $P$ concentrations in two wheat cultivars (Jing 411 and Lovrin 10) grown in hydroponics (a) and in the soil (b). P1 and $\mathrm{P} 2$ refer to 32 and $161 \mu \mathrm{M} \mathrm{P}$ supply, respectively. $\mathrm{J}$ and $\mathrm{L}$ refer to two wheat cultivars Jing 411 and Lovrin 10, respectively. Error bars represent standard errors of means from four replicates.

411 , this could be due to a "dilution effect" since shoot biomass of Lovrin 10 was higher than that of Jing 411 in soil pot.

Compared to higher P supply $(161 \mu \mathrm{M})$, lower P supply $(32 \mu \mathrm{M})$ resulted in more biomass allocated to roots (higher root/shoot ratios, Table 1), which is a standard plant response to $\mathrm{P}$ deficiency (Chapin and Bieleshi, 1982). This pattern also coincided with more absorbed As allocated into roots under $32 \mu \mathrm{M} \mathrm{P}$ supply than under $161 \mu \mathrm{M}$ P supply (Fig. 4(b)). In hydroponics, higher biomass allocation to roots by Lovrin 10 may contribute to relatively higher shoot $\mathrm{P}$ and As concentrations. The hydroponic experiment also demonstrated that there was genotypic difference in As allocation to the aboveground with Lovrin 10 being higher than Jing 411 (Fig. 4(b)).

The shoot-to-root ratios of As concentrations varied from 0.03 to 0.09 (Table 3), indicating that As allocation to the aboveground is relatively low. At the same $\mathrm{P}$ and As additions, Lovrin 10 had higher shoot-to-root ratios of As concentrations than Jing 411. In Arabidopsis, the
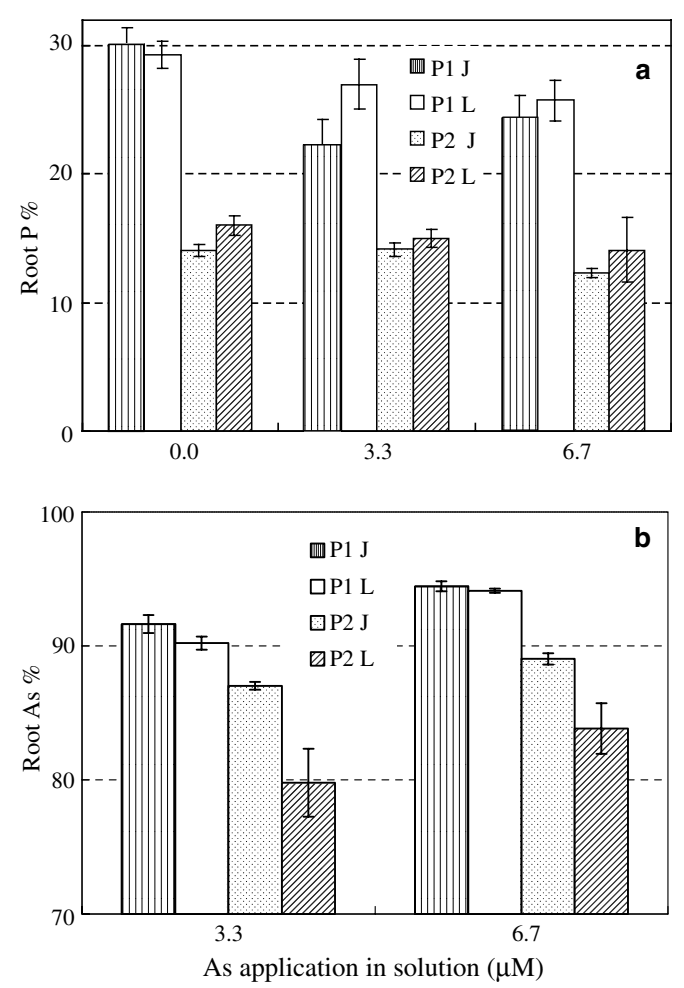

Fig. 4. The percentages of $\mathrm{P}(\mathrm{a})$ and As (b) allocated to roots in two wheat cultivars (Jing 411 and Lovrin 10) pretreated with 32 and $161 \mu \mathrm{M} \mathrm{P}$ for $10 \mathrm{~d}$ and then exposed to three As concentrations $(0,3.3,6.7 \mu \mathrm{M})$ and the corresponding $\mathrm{P}$ concentrations ( 32 and $161 \mu \mathrm{M}$ ) for another $13 \mathrm{~d}$ in hydroponics. P1 and P2 refer to 32 and $161 \mu \mathrm{M}$ P supply, respectively. J and $\mathrm{L}$ refer to two wheat cultivars Jing 411 and Lovrin 10, respectively. Error bars represent standard errors of means from four replicates.

shoot-to-root ratios of As concentrations also varied from 0.03 to 0.07 , but there was little difference between pho2 (a mutant with higher shoot $\mathrm{P}$ concentrations than wild type) and wild type (Geng et al., in press). Other workers have also found similar shoot-to-root ratios of As concentrations, e.g. $<0.02$ in tomato (Lycopersicum esculentum), $<0.1$ in Brassica juncea, and $<0.2$ in rice when arsenate was supplied (Marin et al., 1992; Burló et al., 1999; Pickering et al., 2000; Geng et al., in press). Arsenic allocation to the above ground portion of cereal crops is generally undesirable, as it will reduce the quality of the grains. Our results indicated $\mathrm{P}$ supply may result in relatively higher As allocation to the aboveground (Fig. 4(b)), but absolute shoot As concentrations were inhibited by $\mathrm{P}$ supply, which has practical application in soil-crop systems. Arsenic concentration (3.3 and $6.7 \mu \mathrm{M})$ used in hydroponics commonly exists in soil solution. For example, arsenate concentration in irrigation water was $106 \mu \mathrm{M}$, arsenic concentration in soil solution was $4.3 \mu \mathrm{M}$ in areas with arsenic contamination 
from groundwater and mining activities (Abedin et al., 2002). In such case, $P$ application to the soil may reduce As uptake by crops and hence improve the quality of the grains.

\section{Acknowledgements}

The work was financially supported by the Natural Science Foundation of China (40225002), Ministry of Science and Technology of China (2002CB410808) and the Chinese Academy of Sciences (Hundred Talent Program).

\section{References}

Abedin, M.J., Feldmann, J., Meharg, A.A., 2002. Uptake kinetics of arsenic species in rice plants. Plant Physiol. 128, 1120-1128.

Bates, T.R., Lynch, J.P., 1996. Stimulation of root hair elongation in Arabidopsis thaliana by low phosphorus availability. Plant Cell Environ. 19, 529-538.

Bleeker, P.M., Schat, H., Vooijs, R., Verkleij, J.A.C., Ernst, W.H.O., 2003. Mechanisms of arsenate tolerance in Cytisus striatus. New Phytol. 157, 33-38.

Blum, J.J., 1966. Phosphate uptake by phosphate-starved Euglena. J. Gen. Physiol. 49, 125-137.

Burló, F., Guijarro, I., Carbonell-Barrachina, A.A., Valero, D., Martinez-Sánchez, F., 1999. Arsenic species: effects on and accumulation by tomato plants. J. Agric. Food Chem. 47, 1247-1253.

Carbonell-Barrachina, A.A., Burló, F., Burgos-Hernández, A., López, E., Mataix, J., 1997. The influence of arsenite concentration on arsenic accumulation in tomato and bean plants. Sci. Hortic. 71, 167-176.

Chapin, F.S., Bieleshi, R.L., 1982. Mild phosphorus stress in barley and a related low-phosphorus-adapted barleygrass: phosphorus fractions and phosphate absorption in relation to growth. Physiol. Plant 54, 309-317.

Clark, G.T., Dunlop, J., Phung, H.T., 2003. Phosphate absorption by Arabidopsis thaliana: interactions between phosphorus status and inhibition by arsenate. Aust. J. Plant Physiol. 27, 959-965.

Davies, T.G.E., Ying, J., Xu, Q., Li, Z.S., Li, J., GordonWeeks, R., 2002. Expression analysis of putative highaffinity phosphate transporters in Chinese winter wheats. Plant Cell Environ. 25, 1325-1339.

Dhar, R.K., Biswas, B.K., Samanta, G., Mandal, B.K., Chakraborti, D., Roy, S., Jafar, A., Islam, A., Ara, G., Kabir, S., Khan, A.W., Ahmed, S.A., Hadi, S.A., 1997. Groundwater arsenic calamity in Bangladesh. Curr. Sci. 73, $48-59$.

Dixon, H.B.F., 1997. The biochemical action of arsenic acids especially as phosphate analogues. Adv. Inorg. Chem. 44, 191-227.

Esteban, E., Carpena, R.O., Meharg, A.A., 2003. High-affinity phosphate/arsenate transport in white lupin (Lupinus albus) is relatively insensitive to phosphate status. New Phytol. $158,165-173$.
Föhse, D., Jungk, A., 1983. Influence of phosphate and nitrate supply on root hair formation of rape, spinach and tomato plants. Plant Soil 74, 359-368.

Geng, C.N., Zhu, Y.G., Tong, Y.P., Christie, P., in press. Uptake and translocation of arsenic and phosphorus in pho2 mutant and wild type of Arabidopsis thaliana. J. Plant Nutr.

Jiang, Q.Q., Singh, B.R., 1994. Effect of different forms and sources of arsenic on crop yield and arsenic concentration. Water Air Soil Pollut. 74, 321-343.

Juhasz, A.L., Naidu, R., Zhu, Y.G., Wang, L.S., Jiang, J.Y., Cao, Z.H., 2003. Toxicity tissues associated with geogenic arsenic in the groundwater-soil-plant-human continuum. Bull. Environ. Contam. Toxicol. 71, 1100-1107.

Lin, K.F., Xu, X.Q., Paul, A., Xiang, Y.L., Jin, X., 2001. Relationship between As contents of farmers' hair and of environment in As polluted area. China Environ. Sci. 21, 440-444.

Lu, R.K., 1999. Analytical Methods for Soils and Agricultural Chemistry. China Agricultural Science and Technology Press, Beijing.

Marin, A.R., Masscheleyn, P.H., Patrick, W.H., 1992. The influence of chemical form and concentration of arsenic on rice growth and tissue arsenic concentration. Plant Soil 139, 175-183.

Meharg, A.A., Macnair, M.R., 1992. Suppression of the high affinity phosphate uptake system: a mechanism of arsenate tolerance in Holcus lanatus L. J. Exp. Bot. 43, 519524.

National Research Council, 1977. Arsenic. National Academy Press, Washington, DC.

Neumann, G., Massonneau, A., Langlade, N., Dinkelaker, B., Hengeler, C., Römheld, V., Martinoia, E., 2000. Physiological aspects of cluster root function and development in phosphorus-deficient white lupin (Lupinus albus L.). Ann. Bot. 85, 909-919.

Pickering, I.J., Prince, R.C., George, M.J., Smith, R.D., George, G.N., Salt, D.E., 2000. Reduction and coordination of arsenic in Indian mustard. Plant Physiol. 122, 11711178.

Planas, D., Healey, F.P., 1978. Effects of arsenate on growth and phosphorus metabolism of phytoplankton. J. Phycol. 14, 337-341.

Rothstein, A., Donovan, K., 1963. Interactions of arsenate with the phosphate-transporting system of yeast. J. Gen. Physiol. 46, 1075-1085.

Tu, C., Ma, L.Q., 2003. Interactive effects of $\mathrm{pH}$, arsenic and phosphorus on uptake of As and $\mathrm{P}$ and growth of the arsenic hyperaccumulator Pteris vittata L. under hydroponic conditions. Environ. Exp. Bot. 50, 243-251.

Uthus, E.O., 1992. Evidence for arsenic essentiality. Environ. Geochem. Health 14, 55-58.

Uthus, E.O., 1994. Arsenic essentiality and factors affecting its importance. In: Chappell, W.R., Abernathy, C.O., Cothern, C.R. (Eds.), Arsenic Exposure and Health. Science Reviews Ltd., Northwood, pp. 199-208.

Wang, J.R., Zhao, F.J., Meharg, A.A., Raab, A., Feldmann, J., McGrath, S.P., 2002. Mechanisms of arsenic hyperaccumulation in Pteris vittata. uptake kinetics, interactions with phosphate, and arsenic speciation. Plant Physiol. 130, 15521561. 
Wang, L.F., Zheng, B.S., Wang, S., Lin, Q., Zhang, L., 2002. Water arsenic and its effects on development of Xinjiang (Comprehensive report). Endemic Diseases B 17, 21-24.

Wang, Z.G., He, H.Y., Yan, Y.L., Wu, C.Y., Yang, Y., Gao, X.Y., 1999. Arsenic exposure of residents in areas near Shimen arsenic mine. J. Environ. Health 16, 4-6.

Xie, Z.M., Liao, M., Huang, C.Y., 1997. Effects of arsenic pollution on plants and human health and countermeasures. Guangdong Trace Elem. Sci. 4, 17-21.
Zhu, Y.G., Smith, S.E., 2001. Seed phosphorus (P) content affects growth, and $\mathrm{P}$ uptake of wheat plants and their association with arbuscular mycorrhizal (AM) fungi. Plant Soil 231, 105-112.

Zou, C.Q., Li, J.Y., Li, Z.S., Zhang, F.S., Tong, Y.P., Chen, X.P., Hou, L.J., Wang, X.F., 2002. Photosynthate distribution in wheat varieties differing in phosphorus efficiency. Commun. Soil Sci. Plant Anal. 33, 3767-3777. 